\title{
The influence of dietary tea, coffee and cocoa on protein and energy utilization of soya-bean meal and barley in rats
}

\author{
BY B. O. EGGUM, BIRTHE PEDERSEN AND INGEBORG JACOBSEN \\ National Institute of Animal Science, Department of Animal Physiology and Chemistry, \\ Rolighedsvej 25, DK-1958 Copenhagen, Denmark
}

(Received 11 February 1983 - Accepted 15 April 1983)

1. Two series of balance experiments were performed with growing rats to test the effect of black tea, green tea, coffee and cocoa on protein and energy utilization. In Expt 1 soya-bean meal was fed as a basal diet and supplemented with freeze-dried materials from 1 I black tea, green tea or coffee $/ 500 \mathrm{~g}$ dry matter. Cocoa powder, corresponding to 11 of the beverage, was also added to the basal diet. In Expt 2 the procedure was repeated with a barley-based diet.

2. In both experiments both tea varieties and coffee had significantly negative effects on true protein digestibility and biological value, while digestible energy was only slightly affected in the barley-based diet. Cocoa had no effect on protein or energy utilization in either soya-bean meal or barley diets, although the protein in cocoa powder was completely indigestible.

3. As the tannin concentration in both tea varieties and coffee was very high it is assumed that the observed deleterious effects might, in part, be explained by anti-nutritional effects of tannin.

4. The strongest deleterious effect was recorded for black tea.

Beverages prepared from tea, coffee and cocoa are important constituents of human diets and yet little is known about their effects on nutrient utilization. There is extensive evidence that tea inhibits iron absorption (Stagg \& Millin, 1975; Hessling et al. 1979; Rossander et al. 1979). Naismith et al. (1969) showed that tea, coffee, decaffeinated coffee and caffeine had no effect on growth or feed utilization of young rats, when added to a semi-purified diet, whereas results of Sibbald (1982) suggest that tea and coffee induce reduced digestibility of vegetable protein, while enhancing the utilization of animal protein, in cockerels. As described by Derman et al. (1977) tea polyphenols complex with the casein of added milk, but do not prevent normal digestion of the protein. However, several investigations (e.g. Eggum \& Christensen, 1975) have demonstrated a strong negative relationship between dietary tannin and protein digestibility.

Tea, coffee and cocoa are frequently consumed during or immediately following a meal. Thus, they become immediately mixed with other dietary constituents in a warm, moist environment possibly conducive to chemical interactions. However, according to Stagg \& Millin (1975) tea polyphenols are chemically quite distinct from tannic acid or other commercial tannins and do not induce an adverse gastrointestinal reaction. Although they react with proteins, tea polyphenols do not exhibit the strong irreversible effects associated with true tannins.

Protein constitutes 150-230 g dry weight/ $\mathrm{kg}$ black tea, but less than 20 g hot-water-soluble solids /kg (McCance \& Widdowson, 1960; Das et al. 1964). According to Brown \& Wright (1963) the protein intake from tea alone is unlikely to exceed $70 \mathrm{mg} / \mathrm{d}$ and, therefore, it is insignificant. However, added milk might contribute significant amounts of protein, and althouth casein complexes with tea polyphenols, which reduce the astringency of the tea, this does not prevent normal digestion of the protein.

The present work was undertaken to gain more information on the effect of beverages prepared from tea, coffee and cocoa on protein and energy metabolism. Biological trials were performed with rats and true protein digestibility (TD), biological value (BV), net 
protein utilization (NPU), digestible energy (DE) and true amino acid digestibility (TAAD) were determined.

\section{EXPERIMENTAL}

\section{Diets}

Two protein sources of different quality, soya-bean meal and barley (Expts 1 and 2 respectively) were used to study the effect of black tea, green tea, coffee and cocoa on protein and energy utilization. For each of the three beverages 11 was prepared in a traditional way and freeze-dried. A daily consumption for a man of 11 of either of these beverages has been considered to be a realistic amount. Black and green tea were prepared from $10 \mathrm{~g}$ dry matter (DM) of leaves. For black tea $4.0 \mathrm{~g} \mathrm{DM}$ were dissolved, while $3.5 \mathrm{~g}$ of green tea were soluble. The coffee was prepared from $35.2 \mathrm{~g} \mathrm{DM}$ of finely ground beans and $9.2 \mathrm{~g}$ were dissolved in the beverage. The freeze-dried materials from 11 of the two tea varieties and the coffee and $24 \mathrm{~g}$ cocoa powder were added individually to $500 \mathrm{~g} \mathrm{DM}$ with soya-bean meal (Expt 1) or barley (Expt 2) as the protein source. This amount of food corresponds to approximately $9.6 \mathrm{MJ}(2300 \mathrm{kcal})$, which should be close to the daily requirement of energy of an adult person. Because of the relatively high amount of nitrogen in cocoa powder a preliminary experiment was performed with cocoa, fed together with casein as the protein source. As the protein in casein is completely digestible it was thus possible to get an estimate of the digestibility of the protein in cocoa powder. In total, ten diets were tested as each experiment also included a control diet without the addition of freeze-dried materials from the beverages. The $\mathbf{N}$ content of the diets was adjusted using a basal diet consisting of an N-free mixture according to Eggum (1973). Minerals and vitamins were also added to meet the requirements. The composition of the diets is shown in Table 3 (see p. 201).

\section{Animals and feeding}

The experimental procedure has been described by Eggum (1973). Groups of five Wistar male rats, each weighing approximately $68 \mathrm{~g}$, were used in the experiments with preliminary periods of $4 \mathrm{~d}$ and balance periods of $5 \mathrm{~d}$. Each animal received $150 \mathrm{mg} \mathrm{N}$ and $10 \mathrm{~g} \mathrm{DM}$ daily throughout the preliminary and balance periods. The rats were housed in individual metabolic cages. A $5 \mathrm{~d}$ collection of urine and faeces from each rat was analysed.

\section{Chemical analyses}

Diets were analysed for DM, N, energy and amino acids. Faeces and urine of individual rats were analysed for $\mathrm{N}$ and faeces were also analysed for energy and amino acids. DM and $\mathrm{N}$ were determined according to standard methods (Association of Official Agricultural Chemists, 1975). Gross energy was determined as described by Weidner \& Jakobsen (1962). Amino acid analyses were carried out according to Mason et al. (1980). The freeze-dried materials of tea and coffee and the cocoa powder were analysed for DM, N, ash and tannin. The procedure of Eggum \& Christensen (1975) was used for the determination of tannin.

\section{Statistical analyses}

The results were subjected to one- and two-way analyses of variance and Tukey's HSD test (Gill, 1978). The minimum level of statistical significance accepted was $P<0.05$.

\section{RESULTS}

\section{Chemical composition}

Table 1 shows the values for protein $(\mathrm{N} \times 6.25)$, ash and tannin in soya-bean meal, barley, cocoa powder, black tea, green tea and coffee, and in the residues of black tea, green tea 
Table 1. Concentration $(\mathrm{g} / \mathrm{kg}$ dry matter) of protein (nitrogen $\times 6 \cdot 25)$, ash and tannin in soya-bean meal, barley, black tea leaves, green tea leaves, coffee beans and cocoa powder and their residues after extraction

\begin{tabular}{|c|c|c|c|}
\hline & Protein & Ash & Tannin \\
\hline Soya-bean meal & $498 \cdot 1$ & $69 \cdot 0$ & 1.7 \\
\hline Barley & $118 \cdot 8$ & $25 \cdot 0$ & $4 \cdot 1$ \\
\hline \multicolumn{4}{|l|}{ Black tea } \\
\hline Leaves & $247 \cdot 5$ & $59 \cdot 0$ & $300 \cdot 0$ \\
\hline Residue & $256 \cdot 3$ & $41 \cdot 3$ & 167.9 \\
\hline \multicolumn{4}{|l|}{ Green tea } \\
\hline Leaves & $216 \cdot 9$ & $61 \cdot 3$ & $195 \cdot 5$ \\
\hline Residue & $237 \cdot 5$ & $49 \cdot 1$ & 63.7 \\
\hline \multicolumn{4}{|l|}{ Coffee beans } \\
\hline Finely ground & 147.5 & 43.6 & $84 \cdot 1$ \\
\hline Residue & 113.8 & $13 \cdot 8$ & $14 \cdot 6$ \\
\hline Cocoa powder & $215 \cdot 6$ & $84 \cdot 7$ & 142.4 \\
\hline
\end{tabular}

and coffee after extraction with 11 boiling water. The cocoa was added untreated to the diets, consequently no residue would arise from this product. Both soya-bean meal and barley had protein and ash concentrations normally found in these food items, while the tannin concentration was very low in both protein sources. The protein content in both tea varieties was quite high, with the highest value in black-tea leaves $(247.5 \mathrm{~g} / \mathrm{kg})$. In coffee beans the protein content was much lower, and in cocoa powder the protein content was in between that in tea and coffee. The protein concentration in the residues from both tea and coffee was changed very little as a result of extraction.

The ash content was approximately $60 \mathrm{~g} / \mathrm{kg}$ DM in both tea varieties and somewhat lower in coffee beans; in the cocoa powder it was $84.7 \mathrm{~g} / \mathrm{kg}$ DM. The concentration of ash in the residues was much lower than in the original materials, indicating that significant amounts of minerals were dissolved in the beverages. Tannin was very high in both tea varieties, with $300.0 \mathrm{~g} / \mathrm{kg}$ DM black tea. The content in green tea was much lower $(195.5 \mathrm{~g} / \mathrm{kg} \mathrm{DM})$; coffee beans contained $84.1 \mathrm{~g} / \mathrm{kg}$ DM and cocoa $142.4 \mathrm{~g} / \mathrm{kg} \mathrm{DM}$. The tannin concentration in the residues was much lower than in the corresponding original material, which shows that a large proportion of the tannin was dissolved in the drinkable portion.

The amino acid compositions of soya-bean meal and barley are presented in Tables 6 and 7 respectively (p. 203), together with the values for amino acid digestibility. Soyabean meal is low in sulphur-containing amino acids, the content being far below the requirements for rats. Barley is low in lysine, which is the limiting factor for utilization of barley protein.

Table 2 shows the total amounts of DM applied to prepare 11 tea, coffee and cocoa. For black tea $40 \%$ was dissolved in the beverage, while the corresponding values for green tea and coffee were 35 and $34 \%$ respectively. Relatively less of the protein was extracted during preparation and this would be of no nutritional importance. Approximately $0.3 \mathrm{~g}$ of the ash in tea and $1.2 \mathrm{~g}$ of the ash in coffee were dissolved into 11 beverage, which might be of importance in providing some microminerals. However, most of the tannins were extracted during tea and coffee preparation. For black tea, green tea and coffee 1.99, 1.55 and $2.62 \mathrm{~g}$ tannin respectively would be consumed with 11 beverage and cocoa (1 1 ) would provide $3.42 \mathrm{~g}$ tannin.

The amounts of freeze-dried extracts used in the diets are shown in Table 3 together with the other dietary components. 
Table 2. Dry matter (DM) applied ( $g$ ) and amounts $(g)$ of $D M$, protein (nitrogen $\times 6 \cdot 25$ ), ash, and tannin dissolved when preparing $I l$ of the beverages of tea, coffee and cocoa

\begin{tabular}{lrlll}
\hline & DM & Protein & Ash & Tannin \\
\hline Black tea & & & & \\
$\quad$ Leaves & 10.0 & 2.48 & 0.59 & 3.00 \\
$\quad$ Residue & 6.0 & 1.54 & 0.25 & 1.01 \\
$\quad$ Dissolved in 11 water & 4.0 & 0.94 & 0.34 & 1.99 \\
Green tea & & & & \\
$\quad$ Leaves & 10.0 & 2.56 & 0.61 & 1.96 \\
$\quad$ Residue & 6.5 & 1.41 & 0.27 & 0.41 \\
$\quad$ Dissolved in 11 water & 3.5 & 1.15 & 0.34 & 1.55 \\
Coffee beans & & & & \\
$\quad$ Finely ground & 35.2 & 5.16 & 1.53 & 2.96 \\
$\quad$ Residue & 23.4 & 2.66 & 0.32 & 0.34 \\
$\quad$ Dissolved in 11 water & 11.8 & 2.50 & 1.21 & 2.62 \\
Cocoa powder & 24.0 & 5.17 & 1.96 & 3.42 \\
\hline
\end{tabular}

\section{Expt 1. TD, BV, NPU and DE in soya-bean meal}

As the preliminary study with cocoa powder and casein demonstrated that protein in cocoa was completely indigestible, a correction was made for the protein in cocoa. In this way it was possible to get an estimate of any inhibitory components on protein utilization in cocoa powder. Therefore the values for protein utilization in the diet with cocoa are based on protein from the soya-bean meal only. The protein contribution in the diets from tea and coffee was considered negligible and no effort was made to correct for these small amounts.

TD was negatively affected only by black tea, with a significant decrease from 0.880 to 0.847 (Table 4). Both tea varieties and the coffee had a negative effect on BV, with the strongest decrease from 0.753 in the control group to 0.644 in the group with black tea. The effect of coffee was almost the same as for black tea, while the effect of green tea was less, but still significant. Cocoa had no influence on BV. NPU was affected in the same way as BV. DE was negatively affected only in the group given cocoa, with a significant decrease from 0.879 to 0.853 .

There was no significant difference in food intake or weight gain of rats given the experimental diets. The starting and final weights of each rat were 68 and $85 \mathrm{~g}$ respectively.

\section{Expt 2.TD, BV, NPU and $D E$ in barley}

The group with cocoa was corrected in the same way as in Expt 1. TD was negatively affected by both tea varieties and by coffee, while cocoa had no effect on this value (Table 5). The strongest effect was observed for coffee with a decrease from 0.898 in the control group to 0.849 . Black tea had nearly the same effect as coffee, while the effect of green tea was much less although significant. Cocoa had no effect on TD. As for soya-bean meal, BV was negatively affected by both tea varieties and coffee, with the strongest decrease for black tea from 0.746 in the control group to 0.700 in the group with black tea. Green tea and coffee had a slightly lower effect; cocoa had no influence on BV; NPU was affected in the same way as BV. DE was negatively affected by both tea varieties; however, the effect was rather small. Coffee and cocoa had no significant effect on DE.

There was no significant difference in food intake or weight gain of rats given the experimental diets. The starting and final weights of each rat were 68 and $83 \mathrm{~g}$ respectively. 


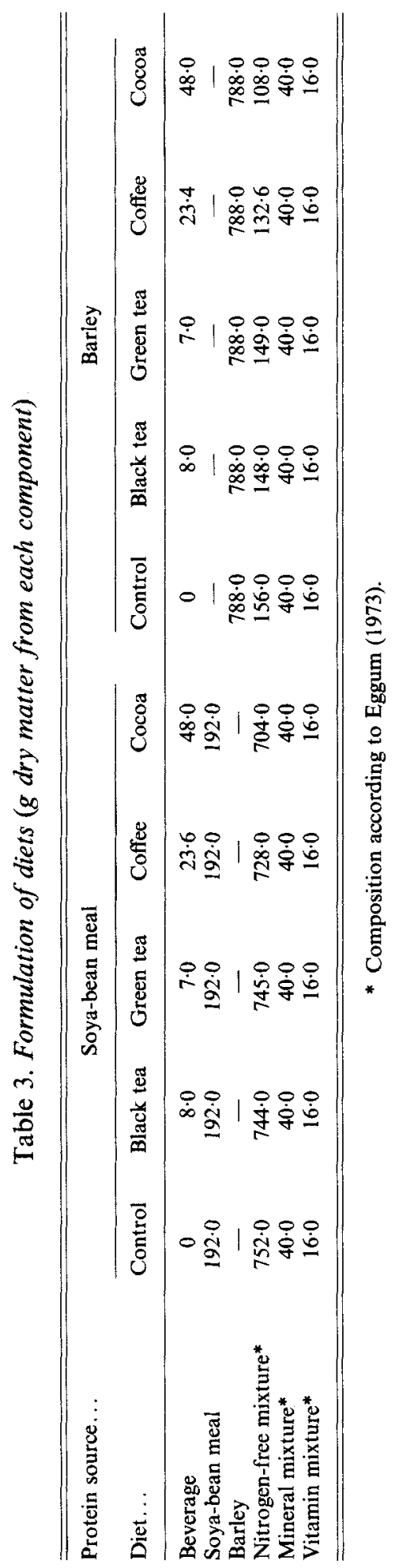


Table 4. Expt 1. The effect of tea, coffee and cocoa on true protein digestibility, biological value, net protein utilization and digestible energy in soya-bean meal

\begin{tabular}{|c|c|c|c|c|c|c|c|}
\hline Treatment... & Control & Black tea & Green tea & Coffee & Cocoa & SEM & $\begin{array}{c}\text { Statistical } \\
\text { significance: } \\
F\end{array}$ \\
\hline True protein digestibility & $0 \cdot 880^{b}$ & $0 \cdot 847^{a}$ & $0 \cdot 866^{b}$ & $0 \cdot 866^{b}$ & $0.871^{b}$ & 0.004 & $7 \cdot 7^{* * *}$ \\
\hline Biological value & $0.753^{c}$ & $0 \cdot 644^{a}$ & $0 \cdot 720^{b}$ & $0 \cdot 647^{a}$ & $0.749^{c}$ & 0.004 & $188 \cdot 4^{* * *}$ \\
\hline Net protein utilization & $0.662^{c}$ & $0 \cdot 545^{a}$ & $0.623^{b}$ & $0 \cdot 562^{a}$ & $0.652^{c}$ & 0.005 & $109 \cdot 6^{* * *}$ \\
\hline Digestible energy & $0 \cdot 879^{b}$ & $0.868^{b}$ & $0 \cdot 870^{b}$ & $0 \cdot 867^{b}$ & $0 \cdot 853^{a}$ & 0.003 & $8 \cdot 9^{* * *}$ \\
\hline
\end{tabular}

$a, b, c$ Mean values that do not share a common superscript letter in the same horizontal row were significantly different $(P<0.05)$.

Values were significantly different: ${ }^{* * *} P<0.001$.

Table 5. Expt 2. The effect of tea, coffee and cocoa on true protein digestibility, biological value, net protein utilization and digestible energy in barley

\begin{tabular}{|c|c|c|c|c|c|c|c|}
\hline Treatment... & Control & Black tea & Green tea & Coffee & Cocoa & SEM & $\begin{array}{c}\text { Statistical } \\
\text { significance: } \\
F\end{array}$ \\
\hline True protein digestibility & $0.898^{d}$ & $0.859^{a b}$ & $0.878^{b c}$ & $0 \cdot 849^{a}$ & $0.890^{\text {cd }}$ & 0.005 & $21 \cdot 0^{* * *}$ \\
\hline Biological value & $0.746^{c}$ & $0 \cdot 700^{a}$ & $0.721^{b}$ & $0.720^{b}$ & $0.744^{c}$ & 0.004 & $18 \cdot 2^{* * *}$ \\
\hline Net protein utilization & $0 \cdot 670^{c}$ & $0 \cdot 602^{a}$ & $0.633^{b}$ & $0.612^{a b}$ & $0.662^{c}$ & 0.005 & $31 \cdot 6^{* * *}$ \\
\hline Digestible energy & $0.824^{c a}$ & $0.805^{a}$ & $0 \cdot 808^{a b}$ & $0.830^{d}$ & $0.818^{b c}$ & 0.003 & $17 \cdot 1^{* * *}$ \\
\hline
\end{tabular}

$a, b, c, d$ Mean values that do not share a common superscript letter in the same horizontal row were significantly different $(P<0.05)$.

Values were significantly different: ${ }^{* * *} P<0.001$.

\section{Expt 1. TAAD in soya-bean meal}

TAAD was, in general, negatively affected by both tea varieties and coffee, while cocoa had no marked influence on these values (Table 6). The values for the most limiting amino acids in soya-bean protein, methionine and cystine were negatively affected by tea and coffee. There was no consistent effect on other amino acids. Glycine and proline digestibilities were low in both groups with tea, while the corresponding values for coffee and cocoa did not seem to be affected.

\section{Expt 2. TAAD in barley}

As for soya-bean protein, black tea, green tea and coffee had a general negative influence on amino acid digestibility, but the effects were more pronounced in barley (Table 7). Cocoa had no marked effect on these values. The digestibility of the most limiting amino acid in barley protein, lysine, was lowered by both tea varieties and by coffee. Alanine, aspartic acid, glycine, isoleucine and threonine also had lower digestibility values.

\section{DISCUSSION}

The results confirm that beverages prepared from black tea, green tea and coffee might have a negative effect on protein and energy utilization in rats. The deleterious effect was especially pronounced on the BV. Cocoa did not seem to contain any inhibitor affecting protein utilization, although the protein in cocoa powder was completely indigestible. The 
Table 6. Expt 1. The effect of tea, coffee and cocoa on true amino acid digestibility* in soya-bean meal. The amino acid composition of soya-bean meal $(\mathrm{g} / \mathrm{kg}$ protein) is also given

\begin{tabular}{|c|c|c|c|c|c|c|}
\hline Treatment... & Control & Black tea & Green tea & Coffee & Cocoa & $\begin{array}{l}\text { Soya-bean } \\
\text { meal } \\
\text { (g/kg protein) }\end{array}$ \\
\hline Alanine & 0.835 & 0.798 & 0.796 & 0.823 & 0.849 & $42 \cdot 2$ \\
\hline Arginine & 0.947 & 0.906 & 0.927 & 0.944 & 0.960 & $71 \cdot 1$ \\
\hline Aspartic acid & 0.903 & 0.876 & 0.888 & 0.903 & 0.901 & $107 \cdot 7$ \\
\hline Cystine & 0.917 & 0.859 & 0.905 & 0.862 & 0.908 & $15 \cdot 1$ \\
\hline Glutamic acid & 0.928 & 0.893 & 0.910 & 0.915 & 0.929 & $178 \cdot 7$ \\
\hline Glycine & 0.858 & 0.801 & 0.828 & 0.850 & 0.820 & $41 \cdot 6$ \\
\hline Histidine & 0.961 & 0.927 & 0.925 & 0.944 & 0.965 & 33.8 \\
\hline Isoleucine & 0.888 & $0 \cdot 853$ & 0.872 & 0.884 & 0.900 & $45 \cdot 1$ \\
\hline Leucine & 0.901 & 0.868 & $0 \cdot 882$ & 0.896 & 0.911 & $74 \cdot 9$ \\
\hline Lysine & 0.902 & 0.872 & 0.881 & 0.901 & 0.917 & 59.9 \\
\hline Methionine & 0.873 & 0.810 & 0.836 & 0.823 & 0.872 & 14.9 \\
\hline Phenylalanine & 0.919 & 0.897 & 0.904 & 0.924 & 0.921 & $52 \cdot 2$ \\
\hline Proline & 0.910 & 0.838 & 0.873 & 0.905 & 0.920 & $49 \cdot 6$ \\
\hline Serine & 0.923 & 0.889 & 0.907 & 0.928 & 0.939 & $49 \cdot 8$ \\
\hline Threonine & 0.864 & 0.825 & 0.845 & 0.873 & 0.867 & $37 \cdot 2$ \\
\hline Tyrosine & 0.895 & 0.851 & 0.862 & 0.900 & 0.893 & $30 \cdot 2$ \\
\hline Valine & 0.849 & 0.836 & 0.852 & 0.870 & 0.844 & $50 \cdot 2$ \\
\hline Protein (nitrogen $\times 6.25$ ) & 0.880 & 0.847 & 0.866 & 0.866 & 0.871 & - \\
\hline
\end{tabular}

* Determined on single samples of pooled faecal material from five rats.

Table 7. Expt 2. The effect of tea, coffee and cocoa on true amino acid digestibility* in barley protein. The amino acid composition of barley protein $(\mathrm{g} / \mathrm{kg}$ protein) is also given

\begin{tabular}{|c|c|c|c|c|c|c|}
\hline Treatment... & Control & Black tea & Green tea & Coffee & Cocoa & $\begin{array}{c}\text { Barley } \\
(\mathrm{g} / \mathrm{kg} \text { protein })\end{array}$ \\
\hline Alanine & 0.840 & 0.781 & 0.799 & 0.787 & 0.850 & $40 \cdot 1$ \\
\hline Arginine & 0.920 & 0.872 & 0.886 & 0.896 & 0.919 & $47 \cdot 1$ \\
\hline Aspartic acid & 0.853 & 0.779 & 0.803 & 0.786 & 0.829 & 53.7 \\
\hline Cystine & 0.936 & 0.882 & 0.905 & 0.914 & 0.942 & $21 \cdot 1$ \\
\hline Glutamic acid & 0.947 & 0.913 & 0.929 & 0.929 & 0.953 & $259 \cdot 9$ \\
\hline Glycine & 0.839 & 0.774 & 0.794 & 0.777 & 0.791 & 37.9 \\
\hline Histidine & $0 \cdot 951$ & 0.899 & 0.910 & 0.922 & 0.962 & 20.7 \\
\hline Isoleucine & 0.907 & 0.855 & 0.871 & 0.859 & 0.913 & 39.0 \\
\hline Leucine & 0.928 & 0.885 & 0.896 & 0.895 & 0.933 & $70 \cdot 8$ \\
\hline Lysine & 0.848 & 0.818 & 0.829 & 0.827 & 0.850 & $32 \cdot 9$ \\
\hline Methionine & 0.913 & $0 \cdot 851$ & 0.872 & 0.872 & $0 \cdot 919$ & $17 \cdot 8$ \\
\hline Phenylalanine & 0.925 & 0.889 & 0.907 & 0.915 & 0.919 & $51 \cdot 8$ \\
\hline Proline & 0.910 & 0.870 & 0.897 & 0.910 & 0.903 & $116 \cdot 6$ \\
\hline Serine & 0.921 & 0.874 & 0.889 & 0.901 & 0.931 & $42 \cdot 2$ \\
\hline Threonine & 0.858 & 0.790 & 0.817 & 0.813 & 0.854 & $33 \cdot 1$ \\
\hline Tyrosine & 0.909 & 0.864 & 0.886 & 0.882 & $0-922$ & $30 \cdot 1$ \\
\hline Valine & 0.879 & 0.844 & 0.864 & 0.851 & 0.886 & $50 \cdot 9$ \\
\hline Protein (nitrogen $\times 6.25$ ) & 0.898 & 0.859 & 0.878 & 0.849 & 0.890 & - \\
\hline
\end{tabular}

* Determined on single samples of pooled faecal material from five rats.

slight decrease in energy digestibility with cocoa powder in the diets is assumed to be due to a very low digestibility of the energy as well as of protein in cocoa. The results indicate that tannin (as well as protein) in cocoa was unavailable and thus passed through the 
digestive tract without ill effects. As cocoa had no measurable effect on the criteria applied in the present study, the discussion will deal with tea and coffee only.

Our results support those of Sibbald (1982), which indicated that tea and coffee induce reduced digestibility of vegetable protein in cockerels. As the chemical analyses show a very high concentration of tannin in both tea varieties and in coffee, it is tempting to assume that tannin is at least one of the factors causing the reduced protein utilization when tea or coffee are fed together with soya-bean meal or barley. This assumption is in agreement with the earlier work of Eggum \& Christensen (1975). However, this contradicts the results of Derman et al. (1977) that tea polyphenols complex with protein but do not prevent normal digestion of the protein. The findings of Stagg \& Millin (1975) support the hypothesis of Derman et al. (1977) that tea polyphenols have no adverse gastrointestinal reaction. However, as discussed by Fenwick \& Hoggan (1976), methods of analysis for tannin determination are rather non-specific and different types of phenolic compounds, including phenolic choline esters, might be included in the values obtained.

Fuller et al. (1967) reported that supplementation with methionine, choline and arginine reduced the toxicity of $1 \%$ dietary tannic acid and completely alleviated the adverse effect of $0.5 \%$ tannic acid. This is believed to result from the need for methyl groups for the O-methylation of gallic acid derived from tannic acid (Potter \& Fuller, 1968), a general phenol-detoxifying mechanism (Williams, 1959), which has also been demonstrated in the rat by Booth et al. (1961). The strong reduction in digestible methionine in soya-bean meal, when given together with tea or coffee, could support this hypothesis. As methionine and cystine are the limiting amino acids in soya-bean protein, the corresponding decrease in BV indicates further a reaction between gallic acid and methionine. Whether this is the main reason for the reduction in BV, when soya-bean meal is given together with tea or coffee, is not known. However, more tannin was extracted from black tea and coffee than from green tea and the two first-mentioned beverages also had the strongest negative influence on protein utilization.

The influence of tea and coffee on protein utilization in barley was slightly different from that in soya-bean meal. TD was relatively more affected, while the influence on BV was less pronounced than for soya-bean meal. As discussed by Eggum \& Christensen (1975), tannin has a negative effect on TD and the amounts of tannin dissolved in 11 of the tea and coffee beverages might explain the changes in TD observed in the groups with tea and coffee extracts in the diets. The group given green tea had the lowest dietary tannin content and the TD in this group was also less affected. The BV was also negatively affected by both teas, as well as by coffee. This may be explained by the lower digestibility of the most limiting amino acid, lysine, in barley protein, when these beverages were given together with barley. There is no general phenol-detoxifying mechanism involving lysine as is the case for methionine. The slight decrease in energy digestibility in both tea groups might also be explained by the tannin extracted from the tea leaves. As discussed by Swain (1965), interference with the action of digestive enzymes by dietary tannin can be expected in view of the general protein-binding properties of tannin. On the other hand, the high content of tannin in the coffee group had no effect on energy digestibility. This indicates that components other than tannin in tea and coffee might be involved in the effects on protein and energy metabolism in rats. To this must also be added that methods of analysis for tannin are rather non-specific and different types of phenolic compounds, including choline esters, might be included in the values obtained (Fenwick \& Hoggan, 1976). 


\section{REFERENCES}

Association of Official Agricultural Chemists (1975). Official Methods of Analysis. Washington DC: Association of Official Agricultural Chemists.

Booth, A. N., Robbins, D. J. \& DeEds, F. (1961). Journal of Nutrition 75, 104-106.

Brown, P. J. \& Wright, W. B. (1963). Journal of Chromatography 11, 504-514.

Das, D. N., Ghosh, J. J. \& Guha, B. (1964). Indian Journal of Applied Chemistry 27, 6-10.

Derman, D., Sayers, M., Lynch, S. R., Charlton, R. W. \& Bothwell, T. H. (1977). British Journal of Nutrition 38, 261-269.

Eggum, B. O. (1973). A study of certain factors influencing protein utilization in rats and pigs. Beretning fra Forsøgslaboratonèt, no. 406.

Eggum, B. O. \& Christensen, K. D. (1975). Breeding for Seed Protein Improvement Using Nuclear Techniques, 229 pp. Vienna: International Atomic Energy Agency.

Fenwick, R. G. \& Hoggan, S. A. (1976). British Poultry Science 17, 59-62.

Fuller, H. L., Chang, S. I. \& Potter, D. K. (1967). Journal of Nutrition 91, 477-481.

Gill, J. L. (1978). Design and Analyses of Experiments in the Animal and Medical Sciences, vol. 1, 409 pp. Iowa: Iowa State University Press.

Hessling, P. B., Klopper, J. F. \& Van Heerden, P. D. R. (1979). South African Medical Journal 55, 631-632.

McCance, R. A. \& Widdowson, E. M. (1960). The Composition of Foods (MRC Special Reports Series No. 297). London: HM Stationery Office.

Mason, V. C., Bech-Andersen, S. \& Rudemo, M. (1980). Zeitschrift für Tierphysiologie, Tierernährung und Futtermittelkunde 43, 146-164.

Naismith, D. J., Akinyanju, P. A. \& Yudkin, J. (1969). Journal of Nutrition 97, 375--381.

Potter, D. K. \& Fuller, J. L. (1968). Journal of Nutrition 96, 187-191.

Rossander, L., Hallberg, L. \& Bjørn-Rasmussen, E. (1979). American Journal of Clinical Nutrition 32, $2484-2489$.

Sibbald, I. R. (1982). Nutrition Reports International 25, 133-137.

Stagg, G. V. \& Millin, J. (1975). Journal of the Science of Food and Agriculture 26, 1439-1459.

Swain, T. (1965). The Tannins in Plant Biochemistry, 552 pp. [J. Bonner and E. V. Varner, editors]. New York: Academic Press.

Weidner, K. \& Jakobsen, P. E. (1962). In Øvelsesvejledning for Landbrugs-, Mejeribrugs- og Licentiatstuderende [D. S. R. Forlag, editor]. Copenhagen, Denmark: Royal Veterinary and Agricultural University.

Williams, R. T. (1959). Detoxification Mechanisms, 2nd ed. New York: Wiley. 